\title{
STUDY OF THE LINGULA IN DRY HUMAN MANDIBLES AND ITS CLINICAL SIGNIFICANCE
}

\section{Umesh P Modasiya ${ }^{1}$, Sanjaykumar D Kanani *2.}

${ }^{1}$ Associate professor, Department of Anatomy, GMERS Medical College, Himmatnagar, India.

${ }^{* 2}$ Assistant professor, Department of Anatomy, GMERS Medical College, Himmatnagar, India.

\section{ABSTRACT}

Introduction: On medial aspect of ramus of mandible, there is small tongue like bony projection located near the margin of mandibular foramina called lingula. It lies close proximity to mandibular foramina, which transmits the inferior alveolar nerve and the corresponding artery to the mandibular canal. Bony derivatives of fisrt brachial arch( Meckel's cartilage) are the spine of sphenoid, maleus, incus and the part of the mandible bearing the lingula.

Materials and Methods: Present study has been carried out on Ninety (180 sides) dry human mandibles of north gujarat population in the anatomy department of various medical college of north gujarat. Height and distance of lingula from various bony landmark of mandible were noted by measuring the following distances using vernier calipers. The mean and standard deviation (S.D) of each measurement was calculated using Microsoft excel.

Result: We noted four different types of shape - triangular, truncated, nodular and assimilated. Truncated lingula(42.22\%) was most prevalent than Nodular(21.67\%), Assimilated(20.56\%), Triangular(15.55\%) shapes. Average height (Mean \pm SD) of the lingula was $7.75 \pm 1.81 \mathrm{~mm}$ on both sides. Average distance of lingular tip to anterior and posterior border of ramus of mandible were $16.62 \pm 3.31 \mathrm{~mm}$ and $15.94 \pm 1.63 \mathrm{~mm}$. Average distance of lingula from mandibular notch and base of mandible were $16.05 \pm 2.85 \mathrm{~mm}$ and $34.16 \pm 2.96 \mathrm{~mm}$.

Conclution: Present study's findings may be helpful for dental surgeons to locate the lingula and important structures nearby while doing surgical procedures to avoid its damage.

KEY WORDS: Lingual, Mandible, Morphology.

Address for Correspondence: Sanjaykumar D Kanani, C - 10, Anupam Colony, Opp - Chirag Diamond, Opp - D mart Bapunagar, Post - Thakkarbapa Nagar, Ahmedabad - 382350, Gujarat, India. Mobile-9879882079 E-Mail: drsanjaykanani@gmail.com

Access this Article online

Quick Response code

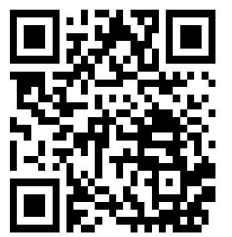

DOI: $10.16965 /$ ijar.2018.160
Journal Information

International Journal of Anatomy and Research

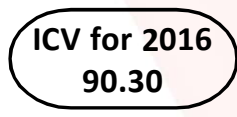

ISSN (E) 2321-4287 | ISSN (P) 2321-8967

https://www.ijmhr.org/ijar.htm

DOI-Prefix: https://dx.doi.org/10.16965/ijar

\section{Article Information}

Received: 22 Feb 2018

Peer Review: 22 Feb 2018

Revised: None
Accepted: 05 Apr 2018

Published (O): 05 May 2018

Published (P): 05 May 2018

\section{INTRODUCTION}

Latin meaning of lingula is lingula mandibulae. On medial aspect of ramus of mandible, there is small tongue like bony projection located near the margin of mandibular foramina [1]. Lingula means "mandibular tongue" was described by Johannes-Baptist Spix(German anatomist) in 1815 , so it was also named as Spix's ossicle or spine [2]. It lies close proximity to mandibular foramina, which transmits the inferior alveolar nerve and the corresponding artery to the mandibular canal [3] It acts as important bony landmark for giving injection of local anaesthetics agent in dental surgery or for excision of nerve for facial neuralgia [4]. Bony derivatives of fisrt brachial arch (Meckel's cartilage) are the spine of sphenoid, maleus, incus and the part of the mandible bearing the 
lingula. Sphenomandibular ligament and anterior ligament of maleus are the embryological remanant of first arch. Lingula provide attachment to sphenomandibular ligament [5]. Becasuse of close relation to neurovascular bundle, present study is conducted to observe the different shapes of lingula and its distance from various bony landmark of mandibles of north Gujarat population and its clinical significance.

\section{MATERIALS AND METHODS}

The present study has been carried out on Ninety (180 sides) dry human mandibles of north gujarat population in the anatomy department of various medical college of north gujarat. The measurements were taken with the help of the Vernier caliper. We noted four different types of shape - triangular shaped lingula[Figure 1], truncated shaped lingula [Figure 2], nodular shaped lingula[Figure 3] and assimilated shaped lingula[Figure 4]. The height and distance of lingula from various bony landmark of mandible were noted by measuring the following distances using vernier calipers. The mean and standard deviation (S.D) of each measurement was calculated using Microsoft excel.

Fig. 1: Triangular Lingula.

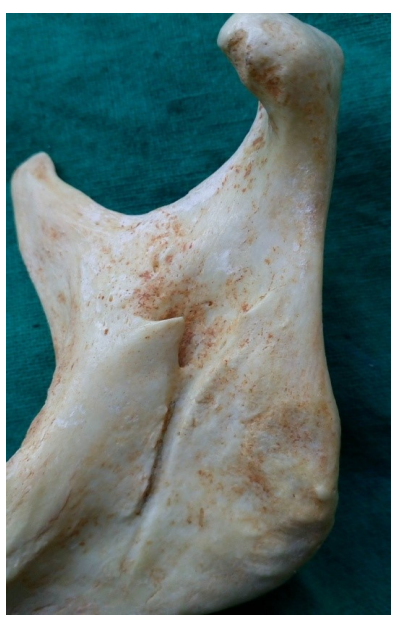

Fig. 2: Truncated Lingula.

Table 2: Height of lingula and its distance from various bony landmark of mandible.
Fig. 3: Nodular Lingula.

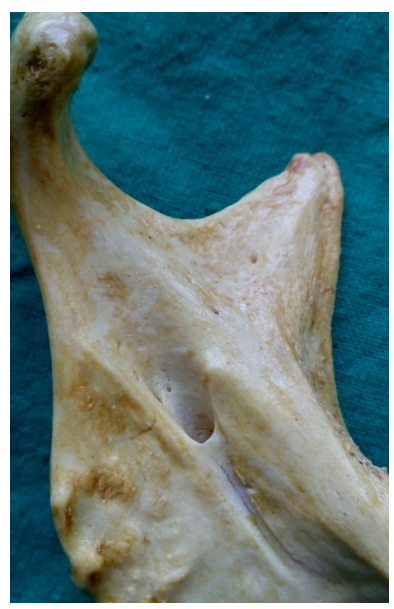

Fig. 4: Assimilated Lingula.

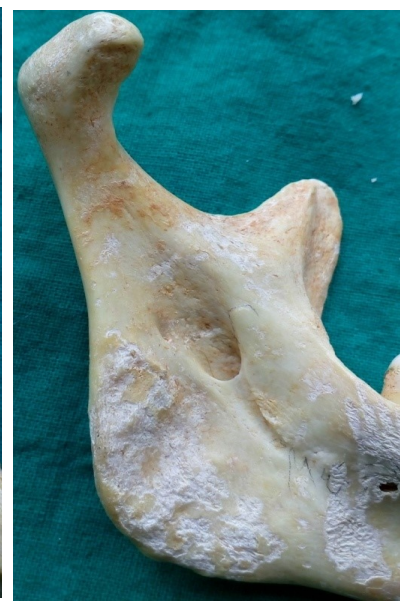

RESULTS

In our study, We observed that, Truncated lingula(42.22\%) was most prevalent than Nodular(21.67\%), Assimilated(20.56\%), Triangu$\operatorname{lar}(15.55 \%)$ shapes. $55.55 \%$ of total mandibles we observered have bilterally symmatry and $45.55 \%$ mandibles were showing different shape of lingula in both side[Table 1].

In present study, the average height (Mean \pm SD) of the lingula was $7.75 \pm 1.81 \mathrm{~mm}$ on both sides. Average distance of lingular tip to anterior and posterior border of ramus of mandible were $16.62 \pm 3.31 \mathrm{~mm}$ and $15.94 \pm 1.63$ $\mathrm{mm}$. Average distance of lingula from mandibular notch and base of mandible were $16.05 \pm 2.85 \mathrm{~mm}$ and $34.16 \pm 2.96 \mathrm{~mm}$. Mean and S.D. of various parameter of right and left sides of mandible were summarized below [Table 2].

Table 1: Different Shape of lingual.

\begin{tabular}{|c|c|c|c|c|c|}
\hline \multirow{2}{*}{ Sr. No. } & \multirow{2}{*}{ Shapes } & \multirow{2}{*}{ Bilateral } & \multicolumn{2}{|c|}{ Unilateral } & Percentage \\
\cline { 4 - 5 } & & & Right & Left & (\%) \\
\hline $\mathbf{1}$ & Truncated & 23 & 20 & 10 & 42.22 \\
\hline $\mathbf{2}$ & Triangular & 8 & 4 & 8 & 15.55 \\
\hline 3 & Nodular & 10 & 10 & 9 & 21.67 \\
\hline 4 & Assimilated & 9 & 6 & 13 & 20.56 \\
\hline
\end{tabular}

\begin{tabular}{|c|c|c|c|c|}
\hline \multirow{2}{*}{ Sr. No. } & Measurements & Right side & Left side & $\begin{array}{c}\text { Average } \\
\text { (both side) }\end{array}$ \\
\cline { 3 - 5 } & Height & $7.88 \pm 1.32$ & $7.61 \pm 2.30$ & $7.75 \pm 1.81$ \\
\hline $\mathbf{1}$ & Mean $(\mathrm{mm}) \pm$ S.D $(\mathrm{mm})$ & Mean $(\mathrm{mm}) \pm$ S.D $(\mathrm{mm})$ & Mean $(\mathrm{mm}) \pm$ S.D (mm) \\
\hline $\mathbf{2}$ & $\begin{array}{c}\text { Distance from } \\
\text { anterior border of } \\
\text { the ramus }\end{array}$ & $17.3 \pm 2.15$ & $15.94 \pm 4.47$ & $16.62 \pm 3.31$ \\
\hline $\mathbf{3}$ & $\begin{array}{c}\text { Distance from } \\
\text { posterior border of } \\
\text { the ramus }\end{array}$ & $15.88 \pm 1.43$ & $16.01 \pm 1.83$ & $15.94 \pm 1.63$ \\
\hline $\mathbf{4}$ & $\begin{array}{c}\text { Distance from } \\
\text { mandibular notch }\end{array}$ & $16.2 \pm 2.32$ & $15.9 \pm 3.37$ & $16.05 \pm 2.85$ \\
\hline $\mathbf{5}$ & $\begin{array}{c}\text { Distance from base of } \\
\text { mandible }\end{array}$ & $34.34 \pm 2.95$ & $33.99 \pm 2.97$ & $34.16 \pm 2.96$ \\
\hline
\end{tabular}




\section{DISCUSSION}

Table 3: Comparison of various studies regarding shapes of lingual.

\begin{tabular}{|c|c|c|c|c|c|}
\hline Author & $\begin{array}{c}\text { Sample } \\
\text { Size }\end{array}$ & $\begin{array}{c}\text { Triangular( } \\
\text { \%) }\end{array}$ & $\begin{array}{c}\text { Nodular } \\
(\%)\end{array}$ & $\begin{array}{c}\text { Truncated } \\
(\%)\end{array}$ & $\begin{array}{c}\text { Assimilated } \\
\text { (\%) }\end{array}$ \\
\hline Tuli et al[1] & 165 & 68.5 & 10.9 & 15.8 & 4.8 \\
\hline Kosithowornchai et al[10] & 144 & 17 & 23 & 47 & 13 \\
\hline Jansisyanont et al[11] & 92 & 29.9 & 19.6 & 46.2 & 4.3 \\
\hline Lopez et al[12] & 80 & 41.3 & 10.5 & 36.3 & 11.9 \\
\hline Nirmale et al[13] & 84 & 47.6 & 27.97 & 13.6 & 10.71 \\
\hline Varma et al[14] & 193 & 13 & 42 & 29 & 6 \\
\hline Smita T et al[15] & 50 & 42 & 10 & 36 & 12 \\
\hline Padmavathi et al[16] & 65 & 29.23 & 19.23 & 33.84 & 17.7 \\
\hline Smrity et al[17] & 102 & 50 & 11.76 & 33.82 & 2.9 \\
\hline Sophia MM et al[18] & 50 & 49 & 23 & 18 & 10 \\
\hline Present study & 90 & 15.55 & 21.67 & 42.22 & 20.56 \\
\hline
\end{tabular}

Table 4: Comparison of various studies for height and distance of lingual.

\begin{tabular}{|c|c|c|c|c|c|c|}
\hline Author & No & $\begin{array}{c}\text { Lingula to anterior } \\
\text { border of ramus } \\
(\mathbf{m m})\end{array}$ & $\begin{array}{c}\text { Lingula to } \\
\text { posterior boprder } \\
\text { of ramus }(\mathbf{m m})\end{array}$ & $\begin{array}{c}\text { Lingula to } \\
\text { manidular notch } \\
(\mathbf{m m})\end{array}$ & $\begin{array}{c}\text { Lingula to base of } \\
\text { mandible (mm) }\end{array}$ & $\begin{array}{c}\text { Height of lingual } \\
\text { (mm) }\end{array}$ \\
\hline Suwadee et al[19] & 72 & $20.70 \pm 2.27$ & $18.88 \pm 3.03$ & $16.41 \pm 3.60$ & $35.79 \pm 3.38$ & - \\
\hline Jansisyanont et al[11] & 92 & $20.6 \pm 2.4$ & $18.0 \pm 2.6$ & $16.6 \pm 2.9$ & - & $8.2 \pm 2.3$ \\
\hline Samanta et al[20] & 100 & $20.0 \pm 2.4$ & $15.0 \pm 2.7$ & $15.4 \pm 2.7$ & - & - \\
\hline Padmavathi et al[16] & 65 & $21.32 \pm 4.12$ & $19.61 \pm 3.30$ & $18.62 \pm 3.71$ & $36.05 \pm 4.12$ & $7.41 \pm 2.23$ \\
\hline Sophia MM et al[18] & 50 & $17.11 \pm 2.32$ & $14.86 \pm 2.54$ & $18.71 \pm 3.18$ & $30.30 \pm 5.11$ & $7.45 \pm 1.48$ \\
\hline Present study & 90 & $16.62 \pm 3.31$ & $15.94 \pm 1.63$ & $16.05 \pm 2.85$ & $34.16 \pm 2.96$ & $7.75 \pm 1.81$ \\
\hline
\end{tabular}

Sphenomandibular ligament attached to lingula because the spine of sphenoid, the sphenomandibular ligament and the part of the mandible bearing the lingula have a common origin from the Meckels cartilage of first branchial arch [5]. The exact reason for the variations in the lingular shapes is not understood. The role of the sphenomandibular ligament in altering the shape is negligible [1]. Lingula is triangular in shape according to standard text books $[3,6]$.

Truncated type was described by Hollinshead [7].Nodular type was described by Berkovitz et al [8].The assimilated type described by Morgan et al[9]. In present study, we found truncated shaped lingula was most prevelant $(42.22 \%)$ which were similar to study done by Kosithowornchaiet al.[10], Jansisyanont et al. [11], Padmavathi et al.[16], Smrity et al.[17]. In contrast to our study, triangular shaped lingula was most prevelat in study done by Nirmale et al.[13], Tuli et al.[1], Lopez et al.[12], Smita T et al.[15], Sophia MM et al.[18]. Triangular shaped lingula was least prevelant in our study, in contast to our study Tuli et al.[1], Jansisyanont et al.[11], Nirmale et al.[13], Varma et al. [14], Padmavathi et al [16], Smrity et al [17], Sophia MM et al.[18] found assimilated shaped lingula were least prevalent in their studies.[Table 3].

In present study, the average height (Mean \pm SD) of the lingula was $7.75 \pm 1.81 \mathrm{~mm}$ on both sides which is similar to study conducted by Padmavathi et al.[16] and Sophia MM et al.[18]. Average distance of lingular tip to anterior and posterior border of ramus of mandible was 16.62 $\pm 3.31 \mathrm{~mm}$ and $15.94 \pm 1.63$ which is less as copare to other studies. Average distance of lingula from mandibular notch and base of mandible were $16.05 \pm 2.85 \mathrm{~mm}$ and $34.16 \pm 2.96$ $\mathrm{mm}$ which were more or less similar to the findings of other studies.[Table 4]. The knowledge of shape, position and height of lingula is important to oral and maxilla-facial surgeons while doing procedures like bilateral sagittalsplit ramus osteotomy, intra oral vertical ramus osteotomy and inferior alveolar nerve block. It is also helpful in anthropology,anatomists and 
forensic study.

\section{CONCLUSION}

The present study provides information regarding the shapes, height and location of the lingula in relation to the mandibular landmarks in north Gujarat population. These findings may be helpful for dental surgeons to locate the lingula and important structures nearby while doing surgical procedures to avoid its damage.

\section{Conflicts of Interests: None}

\section{REFERENCES}

[1]. Tuli A, Choudhry R, Choudhry S, Raheja S, Agarwal S. Variation in shape of the lingula in the adult human mandible. J Anatomy. 2000; 197(2):313-317.

[2]. Dobson J. Anatomical Eponyms. 2nd Ed. Edinburg, London: E and S ivingstone.1962; p.194.

[3]. Standring S, Collins P, Healy JC, Wigley C, Beale TJ. Mandible: Infratemporal and pterygopalatine fossae and temporomandibular joint. Gray's Anatomy - The Anatomical Basis of Clinical Practice, Fortieth edition. Churchill Livingstone, Elsevier. 2008. p. 530-532.

[4]. Basmajian JV Grant's Method of Anatomy, 10th edn. Baltimore, London: Williams \& Wilkins.1980; p.474.

[5]. Moore KL, Persaud TVN. The Developing HumanClinically Oriented Embryology, Seventhedition, Saunders, Philadelphia. 2003: 204.

[6]. Sinnatamby CS. Mandible, Osteology of skull and hyoid bone. Last's Anatomy, Regional and Applied. Eleventh edition. Churchill Livingstone, Elsevier. 2006. p. 532-533.

[7]. Hollinshead W H. Textbook of Anatomy. First edition. Calcutta, India: Harper and Row.1962; p: 855856.

[8]. Berkovitz BKB, Holland GR, Moxham BJ. Colour atlas and textbook of oral anatomy. Second edition.London: Wolfe Medical Publication. 1978; $\mathrm{Pp}: 15$.

[9]. Morgan DH, House LR, Hall WP, Vamuas S J. Diseases of temporomandibular apparatus. Second edition. Saint Louis: CV Mosby. 1982 ; Pp: 19
[10].Kositbowornchai S, Siritapetawee, Damrongrungruang T, Khongkankong W, Chatrchaiwiwatana S, Khamanarong K, ChanthaoopleeT. Shape of the lingula and its localization by panoramic radiograph versus dry mandibular measurement. Surg Radiol Anat. 2007;29(8):689-694.

[11]. Jansisyanont P, Apinhasmit W, Chompoopong S. Shape, height and location of the lingula forsagittal ramus osteotomy in Thais. Clin.Anat 2009;22: 78793.

[12]. Lopes PTC, Periera GAM, Santos AMPV. Morphological Analysis of the lingula in dry mandibles of individuals in Southern Brazil. J Morpholog Sci.2010; 27(3-4):136-138.

[13]. Nirmale VK, Mane UW, Sukre SB, Diwan CV. Morphological Features of Human Mandible. Int J of Recent Trends in Sci Technol. 2012; 3 (2): 38-43.

[14]. Varma CL, Sameer PA. Morphological variants of Lingula in south Indian Mandibles. RRJHMS , January to March 2013; 2(1):31-34.

[15]. Smita T. Variations in the Morphological appearance of lingula in dry adult human mandibles, Int J of Cur Res Rev. 2013; 5(24):41-45

[16]. Padmavathi G, Varalakshmi KJ, Suman T, Roopashree K. A Morphological and morphometric study of the lingula in dry adult human mandibles of South Indian origin and its clinical significance. International Journal of Health Sciences and Research. 2014; 4(6): 56-61.

[17]. Smrity G, Krishna P. Morphological analysis of the lingula in dry mandibles of individuals in North India Journal of Dental and Medical Sciences. 2014; 13(1):4-6.

[18]. Sophia MM, Alagesan A,Ramchandran K. A Morphometric and Morphological Study of mandibular lingula and its Clinical Significance, International Journal of Medical Research and Review, March, 2015/ Vol 3/ Issue 2:141-148.

[19]. Suwadee K, Mookdha S, Teerasak D, Waranyoo K,Supaporn C, Kimaporn K, Tanarat C. Shape of the lingula and its localisation by panaromic adiographversus dry mandibular measurements. Surg Radiol Anat. 2007; 29:689-694.

[20]. Samanta PP, Kharab P. Morphological Analysis of Lingula in Dry Adult Human Mandibles of North Indian Population. J Cranio Max Dis 2012;1: 7-11.

How to cite this article:

Umesh P Modasiya, Sanjaykumar D Kanani, STUDY OF THE LINGULA IN DRY HUMAN MANDIBLES AND ITS CLINICAL SIGNIFICANCE. Int J Anat Res 2018;6(2.2):5218-5221. DOI: 10.16965/ijar.2018.160 